\title{
Embryos and yolk-sac larvae of turbot Scophthalmus maximus are infested with an endoparasite from the gastrula stage onwards
}

\author{
Benedikte Hedegaard Pedersen \\ Marine Biological Laboratory, University of Copenhagen, Strandpromenaden 5, DK-3000 Helsinger, Denmark
}

\begin{abstract}
An organism which under light microscopy is indistinguishable from a protistan endoparasite found in larval cod Gadus morhua was discovered in turbot Scophthalmus maximus embryos and yolk-sac larvae. The organism exhibits a predilection for the same sites as the cod parasite and is probably lethal for the fish larvae.
\end{abstract}

KEY WORDS: Turbot eggs and larvae - Protistan endoparasite

A previous paper (Pedersen et al. 1993) described the finding of a protistan endoparasite in the yolk of embryos and larvae derived from wild cod Gadus morhua. The only other example in the literature of a similar phenomenon was reported for larvae of the sardine Sardina pilchardus by Hollande \& Cachon (1952, 1953), who diagnosed the sardine endoparasite as a dinoflagellate, Ichthyodinium chabelardi. The infested sardine larvae died due to the parasite's rupturing the yolk sac (Hollande \& Cachon 1952, 1953).

The present paper reports on an endoparasite found in the yolk of eggs and larvae of turbot Scophthalmus maximus.

Materials and methods. The investigations were carried out in May and June 1993 at a fish farm adjacent to the western part of the Baltic Sea. Eggs from the broodstock and in one case from a wild female turbot were used. The broodstock and the fertilised eggs were kept at a salinity of 15 ppt in flow-through containers in which the water was continuously renewed from the Baltic. In each case, eggs from 1 female turbot were stripped and artificially fertilised with sperm from 2 males. The resulting embryos were incubated in the dark at 13 to $14^{\circ} \mathrm{C}$. At intervals embryos were screened for the presence of the parasite, and infested embryos were isolated in microtest plates for study of parasite development. One batch of eggs was trans- ferred to Helsingør and incubated in stagnant water at $20 \mathrm{ppt}$ and $16^{\circ} \mathrm{C}$ for photography. The parasites were photographed in situ in live larvae.

Results. Eight batches of eggs were studied, and all except one batch were infested. The recorded incidences of infestation were $21.5 \%(n=121), 20.0 \%$ $(n=55), 0 \%(n=50)$, and $40.4 \%(n=47)$. The incidence of $40.4 \%$ was from the wild female turbot. The given incidences are minimum values, as eggs were screened at 25 to $50 \times$; at this magnification only the largest parasites are seen. Further, the parasite may seemingly disappear with time. In 9 infested eggs isolated $2 \mathrm{~d}$ after fertilisation - in the gastrula stage - the parasite was no longer visible $5 \mathrm{~d}$ later in the yolk-sac larvae $(50 \times)$. Also, in 3 out of 9 infested eggs, the parasite 'disappeared' in $2 \mathrm{~d}$. At $250 \times$, however, numerous small parasites were observed throughout the yolk of these 3 larvae.

Most embryos contained 1 to 2 large parasites. Upon increasing the magnification to $100 \times$, infested embryos were seen to contain several parasites with varying diameters (Table 1). The surface of the larger parasites was irregular, and the smaller parasites were located nearby (Fig. 1C, D). As is the case with larval cod (Pedersen et al. 1993) the typical location of the parasite is ventral and lateral to the middle section of the embryonic body, inside the yolk sac (Fig. 1A, B, E). Infrequently, the parasite is located outside the yolk in the interstice between the yolk-sac membrane and the surface epithelium of the larval body. This rare location has also been observed in cod larvae and embryos (own unpubl. data). In turbot, the parasite can be identified in the early gastrula phase where it is found ventral to the body or just outside the lip of the blastopore. 
Table 1 Diameters of parasites in individual turbot Scophthalmus maximus embryos observed at $100 \times$. Embryo Nos. 1 to 10 belonged to one batch. Nos. 11 to 23 to another. Diameters are in $\mu \mathrm{m}$

\begin{tabular}{|cl|cl|}
\hline Larva no. & $\begin{array}{l}\text { Parasite } \\
\text { diameters }\end{array}$ & Larva no. & $\begin{array}{l}\text { Parasite } \\
\text { diameters }\end{array}$ \\
\hline 1 & $50,40,13$ & 12 & 60 \\
2 & 70 & 13 & 45 \\
3 & 65 & 14 & 50 \\
4 & $65,13,10$, & 15 & 35 \\
& $10,10,10$ & 16 & $60,15,15$ \\
5 & 68 & 17 & 60 \\
6 & 60 & 18 & 70,20 \\
7 & $69,11,10,10$ & 19 & 50 \\
8 & 65,13 & 20 & 65 \\
9 & $70,10,7$ & 21 & 70 \\
10 & 60 & 22 & 50 \\
11 & 82 & 23 & 80 \\
\hline
\end{tabular}

Discussion. The appearance of the turbot parasite under light microscopy is identical to that observed in larval cod (Pedersen et al. 1993); in both turbot and cod the surface of the largest parasites is irregular and can exhibit various protuberances or indentations (Fig. 1C, $D, E)$. The differences in surface structure probably reflect differences in developmental stage of the parasite. The surface of the smaller parasites is less irregular (Fig. 1C; cf. also Fig. 1C in Pedersen et al. 1993). The locations and diameters ( 70 to $80 \mu \mathrm{m}$ ) of the larger parasites seen during screenings correspond exactly to those in cod larvae, so the preliminary findings strongly indicate that the same organism is parasitizing both species of fish. The apparent disappearance of the larger turbot parasites is in accordance with transmission electron microscope observations in larval cod (Pedersen et al. 1993) showing large, multinucleated parasites in the process of breaking up into numerous mononucleated organisms. The present parasite differs from that described by Hollande \& Cachon (1952, 1953 ) as it does not disrupt the yolk sac in either cod (Pedersen et al. 1993) or turbot larvae. The presence of the parasite in these 2 economically important fish species is noteworthy, however, as preliminary findings show that larval cod die as a consequence of being infested (Pedersen \& Køie unpubl.).

Fig. 1. Light microscopy of turbot Scophthalmus maximus parasites (in situ). (A) Typical location (arrow) of a large parasite in the yolk of a hatching embryo. Scale bar $=400 \mu \mathrm{m}$. (B) Parasite (arrow) in the yolk of a $1 \mathrm{~d}$ old larva. Scale bar = $100 \mu \mathrm{m}$. (C) Five parasites (arrows) of varying sizes in the yolk sac. Scale bar $=43 \mu \mathrm{m}$. (D) Parasites in the yolk sac (arrows). Note the pitted surface of the larger specimen. Scale bar = $33 \mu \mathrm{m}$. (E) A large parasite (arrow) in the yolk sac. Same specimen as in (A). Scale bar $=47 \mu \mathrm{m}$
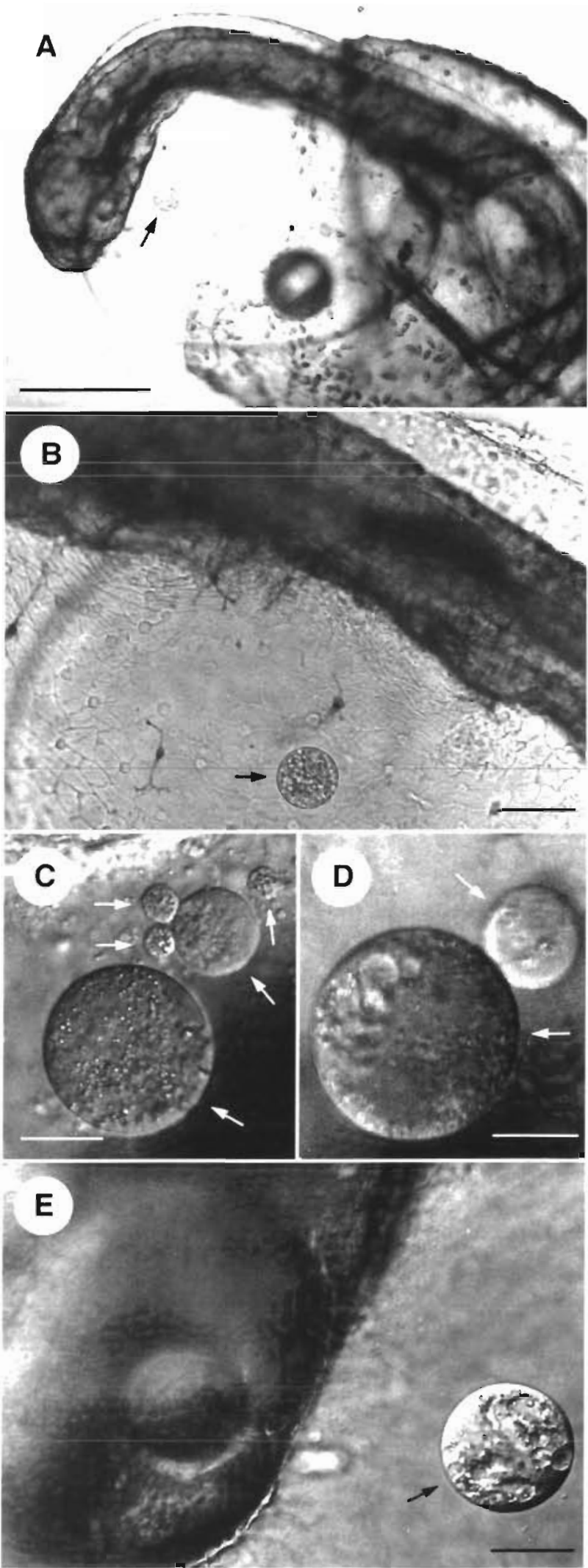


\section{LITERATURE CITED}

Hollande, A., Cachon, J. (1952). Un parasite des œufs de sardine: l'Ichthyodinium chabelardi, nov. gen., nov. sp. C. r. Acad. Sci., Paris (Sér. D) 235: 976-977

Hollande, A., Cachon, J. (1953). Morphologie et évolution

Responsible Subject Editor: W. Körting, Hannover, Germany d'un péridinien parasite des culs de sardine (IChthyodinium chabelardi). Station d'Aquiculture et de Pêche de Castiglione (Alger) 4: 7-17

Pedersen, B. H., Buchmann, K., Køie, M. (1993). Baltic larval cod Gadus morhua are infested with a protistan endoparasite in the yolk sac. Dis. aquat. Org. 16:29-33

Manuscript first received July 22, 1993

Revised version accepted: August 31, 1993 